\title{
Biodiversity of microcrustaceans (Cladocera, Copepoda) in a lowland river ecosystem
}

\author{
Maciej KARPOWICZ* \\ University of Bialystok, Institute of Biology, Department of Hydrobiology, Bialystok, Poland \\ *Corresponding author: m.karpowicz@uwb.edu.pl
}

\begin{abstract}
This study presents comprehensive research on microcrustacean diversity in different types of aquatic environments in the Upper Narew Valley over five years. A total of 559 samples were analyzed, and 74 species of crustacean zooplankton were identified. Metacyclops planus (Gurney, 1909) is a new species for the fauna of Poland and was found in oxbow lakes and tributary streams. The results of the study suggest that oxbow lakes, with more than $80 \%$ of all recorded species, may significantly contribute to the regional biodiversity of floodplain rivers. The highest crustacean community diversity was observed in the semi-lotic oxbow lakes, which emphasizes the role of intermediate disturbance in enhancing biodiversity of water bodies in river valleys. Generally, more 'heterogeneous' habitats, such as small oxbow lakes and tributary streams, had higher crustacean species richness. However, a sampling station that was quite 'homogeneous', the Narew River upstream the Siemianówka Reservoir, had high crustacean species richness. The species accumulation curves revealed that approximately 50-100 zooplankton samples taken from different environments of river valley are required to establish crustacean species richness. These data could be important for river catchment management and could act as pilot survey data for monitoring plans.
\end{abstract}

Key words: Zooplankton; species richness; oxbow lakes; floodplain; river basin management.

Received: February 2016. Accepted: June 2016.

\section{INTRODUCTION}

River corridors have been recognized as linear landscapes in which water flow plays a key role in connecting various landscape patches (Junk et al., 1989; Malanson, 1993; Ward, 1998). Floodplain rivers are characterized by fluvial dynamics that create complex habitats and connectivity gradients, which result in high biodiversity (Ward and Tockner, 2001). Small water bodies of floodplain rivers are usually fully overgrown by macrophytes, which shape the structural environment for a variety of invertebrates (Stansfield et al., 1997; Cazzanelli et al., 2008). Therefore, even if a pond is small and shallow, it is crucial to conduct research in various microhabitats that vary in their spatial complexity (Kuczyńska-Kippen and Joniak, 2015). These shallow water bodies in river valleys are important for biodiversity conservation (Biggs et al., 1994), but they have been lost on a large scale during the twentieth century (Hull, 1997). Knowledge of the biodiversity of different types of water bodies is important for protecting the river valley and achieving sustainable catchment management (Schneiders and Verheyen, 1998). Unlike in terrestrial ecology, there is no tradition in aquatic ecology for exhaustive species censuses that handle the full set of subhabitats (including the species-rich littoral zone) of individual lakes. Reliable data are restricted to those few lakes on which a long his- tory of cumulative observations exist (Dumont and Segers, 1996). Data on changes in geographical distribution of planktonic invertebrates can be used to detect the influence of global climate changes on ecosystems (Dziuba et al., 2013), but first the biodiversity of lowland river habitats has to be established.

The faunistic data on microcrustaceans (Cladocera and Copepoda) in Eastern Poland are scarce and limited to general information from lakes, which is usually gathered during ecological monitoring. The latest data on zooplankton in natural river ecosystems of NE Poland came from the protection plan of Narew National Park and Biebrza National Park. These data revealed a high diversity of Crustacea (Ejsmont-Karabin and Karabin, 2004). Most studies of plankton dynamics in rivers are conducted in a single type of habitat, such as the main river channel or oxbow lakes. The main aim of this study was to comprehensively survey the spatial patterns of microcrustacean species richness and diversity in the different types of aquatic ecosystems in a semi-natural lowland river valley. The second goal was to investigate how the connectivity of oxbow lakes affects the zooplankton biodiversity. These data could be important in lowland river catchment management and could act as pilot survey data for monitoring plans. The third goal was to establish the sampling effort required to discover microcrustacean species richness in the different types of aquatic ecosystems. 


\section{METHODS}

\section{Study area}

The hydrological regime of the Upper Narew River features one period of water-level rise, related to snow melting in the spring, and one period of low-water level, from July to October. The mean annual discharge of the river at the Suraż gauging station is $13.3 \mathrm{~m}^{3} \mathrm{sec}^{-1}$, and the maximum recorded discharge was $250 \mathrm{~m}^{3} \mathrm{sec}^{-1}$ (Gradziński et al., 2000). The Narew River is a typical lowland floodplain river with a dam reservoir. The Siemianówka Reservoir (SR) is a large and shallow lowland water body (maximum area $32.5 \mathrm{~km}^{2}$, maximum capacity $79.5 \mathrm{~km}^{3}$, mean depth $2.5 \mathrm{~m}$ ) with a mean water residence time from four to six months. The water quality in the SR varies in different seasons but is always at a eutrophic to hypertrophic level, with strong cyanobacteria blooms in summer (Grabowska, 2005; Górniak and Karpowicz, 2014; Grabowska and Mazur-Marzec, 2014). The Narew River upstream the Siemianówka Reservoir (Fig. 1) is a natural river surrounded by a floodplain and a swamp. The Narew River downstream the SR is a meandering river with a semi-natural catchment. The section of Narew River between 90 and $130 \mathrm{~km}$ below the dam is an anastomosing system, which consists of a network of interconnected channels and inter-channels (Fig. 1). This section is protected by the Narew National Park (NNP). Below the $\mathrm{NNP}$, the valley is strongly altered by drainage works, and

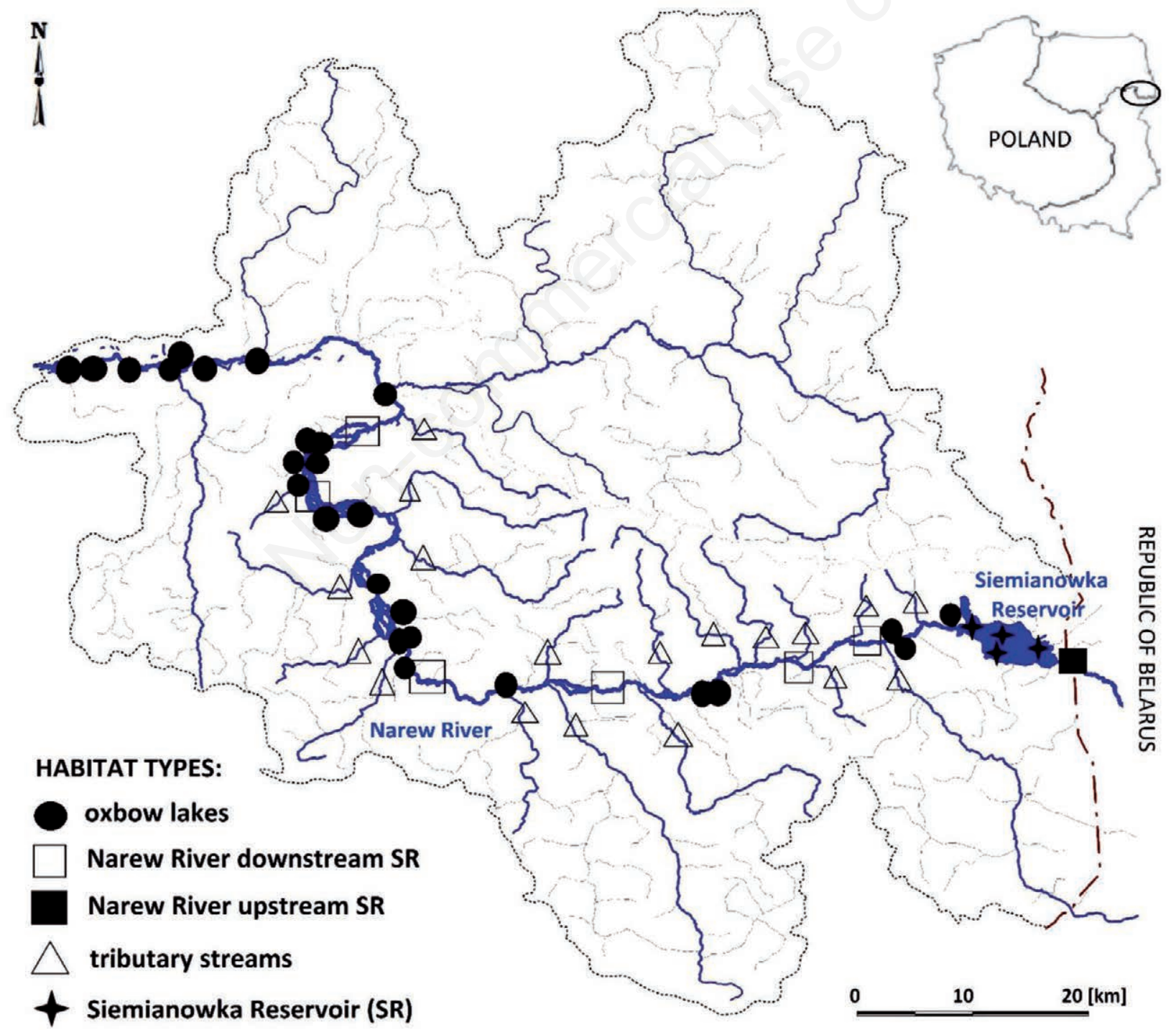

Fig. 1. Map of the study sites with the locations of the sampling stations. 
the river becomes regulated by a large number of oxbow lakes. Tributary streams and oxbow lakes are usually shallow and have aquatic vegetation. The most common and dominant macrophytes were: Ceratophyllum demersum L., Elodea canadensis Michx., Stratiotes aloides L. and Spirodela polyrhiza (L.).

\section{Zooplankton analyses}

Zooplankton samplings were performed over five years (2009-2013) in different environments of the lowland river (Fig. 1). The total number of samples and the frequency of sampling in different ecosystems of the river valley are in Tab. 1. The samples from the Siemianówka Reservoir were collected monthly from four stations over five years (Tab. 1). One sampling station was in the littoral zone with Phragmites australis (Cav.) Trin. Ex. Steudel and Potamogeton perfoliatus L. Three stations were located in the open water zone of the Siemianówka Reservoir (Fig. 1), and the deepest stations were near the dam, where sampling was conducted at depths of $0,2,3$, and 6 $\mathrm{m}$. There were six sampling stations in the $130-\mathrm{km}$ section of the Narew River downstream the SR (Fig. 1), in the meandering and anastomosing section of river. Narew River upstream the SR is a single sampling station, which represent a natural river surrounded by wetlands. The samples from the Narew River were taken from the main current by a sample bucket. The samples from the tributary streams and oxbow lakes were taken by a telescopic water sampler from the open water zone and from the dominant aquatic vegetation. Additionally, three types of oxbow lakes with various connections to the riverbed were distinguished in the zooplankton analyses. Lentic oxbow lakes have a limited hydrological connection to the main river. Semi-lotic oxbow lakes are hydrologically classified between cut-off and open-lotic reservoirs (Obolewski et al., 2015).

Crustacean zooplankton (Cladocera and Copepoda) were sampled using different $5 \mathrm{~L}$ samplers with four replicates $(20 \mathrm{~L})$. The samples were concentrated using a plankton net with a 50- $\mu \mathrm{m}$ mesh size and were preserved in solution of $4 \%$ formaldehyde. The species were identi- fied using specialized taxonomic literature (Smirnov, 1996; Flössner, 2000; Dussart and Defaye, 2001; Rybak and Błędzki, 2010). Copepoda from the order Calanoida and Cyclopoida were determined to the species level, Harpacticoida were only counted.

Non-metric multidimensional scaling (NMDS) was used to visualize differences in zooplankton communities. The data of species frequency in different types of aquatic ecosystems (Supplementary Tab. 1) were used to create a Bray-Curtis similarity matrix as the input for NMDS. Ordination of barycentres give a synthetic representation of the crustacean communities in different environments of the river valley. NMDS is an ordination technique that is relatively insensitive to data distributions (i.e., non-normality and non-linearity) compared to other multivariate ordination methods (Pothoven and Fahnenstiel, 2014). Species accumulation curves based on the calculated and estimated species richness were used to compare crustacean diversities between different environments of the Narew River. The Chao 2 non-parametric estimator was used to assess species richness in the studied environments based on the observed number of species (Basualdo, 2011). Rarefaction curves were created using EstimateS software, ver. 9 (Colwell, 2013). The biodiversity of crustacean communities in different environments of the Upper Narew Valley was expressed by the number of species (total, average and estimated), Shannon index, Berger-Parker dominance index, and evenness index. The biodiversity indices were calculated using Biodiversity Pro: Free Statistics Software for Ecology (McAleece et al., 1997). The Shannon diversity index was calculated using the formula:

$\mathrm{H}^{\prime}=-\sum \mathrm{p}_{\mathrm{i}} \ln \mathrm{p}_{\mathrm{i}}$,

where pi is the relative abundance of species $\left(p_{i}=n_{i} / N ; n_{i}\right.$ is the number of individual species, and $\mathrm{N}$ is the total number of individuals).

The crustacean community parameters in different environments were visualized with box plots (mean, median, first and third quartiles, standard deviation, minimum and maximum). The differences between samples were tested with non-parametric Kruskal-Wallis tests. Probability lev-

Tab. 1. Characteristics of sampling stations in different ecosystems of the Upper Narew River.

\begin{tabular}{lccc} 
& Number of sampling stations & Total number of samples & Frequency of sampling \\
Siemianówka Reservoir & 4 & 257 & Monthly over five years (2009-2013) \\
\hline Narew River downstream SR & 6 & 99 & Biweekly during growing seasons (2010-2011) \\
\hline Narew River Upstream SR & 1 & 42 & Monthly over five years (2009-2013) \\
\hline Tributary streams & 19 & 43 & During growing seasons (2010-2013) \\
\hline Oxbow lakes & 41 & 109 & During growing seasons (2010-2013) \\
\hline
\end{tabular}

SR, Siemianówka Reservoir. 
els of $\leq 0.05$ were considered significant. Statistical analyses were performed with XLSTAT (Addinsoft, 2012).

\section{RESULTS}

In total, 559 samples were analyzed, and 73 species of crustacean zooplankton were found in the Upper Narew Valley, including 47 species of Cladocera and 26 Copepoda. Metacyclops planus (Gurney, 1909) is a new species for the fauna of Poland and was found in the oxbow lakes and tributary streams. Some of the identified species are rare in Poland, such as Camptocercus fennicus, Phreatalona rustica, Acanthocyclops americanus and Diacyclops abyssicola. The most common species in the Upper Narew Valley were species with wide ecological valence, such as Chydorus sphaericus, Bosmina longirostris, and Mesocyclops leuckarti, and species typical of the littoral zone and aquatic vegetation, such as Acroperus harpae, Alonella nana, Alona quadrangularis, Coronatella rectangula, Ceriodaphnia quadrangula, Disparalona rostrata, Pleuroxus aduncus, Ectocyclops phaleratus, Eucyclops macruroides, and Macrocyclops albidus. The largest source of pelagic species (Bosmina coregoni, Daphnia cucullata, Leptodora kindtii, Cyclops scutifer) in the Upper Narew Valley was the Siemianówka Reservoir, where these species were noted in the highest frequencies and highest abundances. The NMDS plot indicated that the zooplankton species in the Narew River (downstream and upstream of the SR) were similar to the species in the SR (Fig. 2). The zooplankton assemblages in the oxbow lakes and tributary streams were well separated (Fig. 2) and dominated by littoral and benthic species.

Oxbow lakes had the highest total number of microcrustacean species (62 species), which composed more than $80 \%$ of all species the from the Upper Narew Valley. Sixteen species were found exclusively in oxbow lakes. Despite having the largest number of analyzed samples, the Siemianówka Reservoir had the lowest total number of species (32 species). A similar number of crustacean species was recorded in all lotic habitats. The Narew River downstream the SR had 35 species, the Narew River upstream the SR had 35 species, and tributary streams had 34 species. However, the variance among curves based on Chao 2 estimator showed that crustacean richness in the Narew River upstream the SR (single sampling station) was much higher than in the Narew River downstream the SR (six sampling stations in the Narew River at the distance $130 \mathrm{~km}$ below the SR) (Fig. 3). Tributary streams and Narew upstream SR have similar species number distribution, similar total number of species and similar number of analyzed samples. As a results, curves of accumulated crustacean species richness are superimposed in most cases (Fig. 3).

The curves based on the Chao 2 estimator revealed high crustacean richness in oxbow lakes, Narew River up- stream SR and tributary streams (Fig. 3). These data showed that accumulation curves from various environments in river valley are close to the plateau at $50-100$ samples (Fig. 3). Generally more heterogeneous habitats (e.g., oxbow lakes, tributary streams) should be more intensively sampling.

The highest diversity of crustacean communities was observed in the oxbow lakes. The Shannon index (Fig. 4C) and the average number of species (Fig. 4A) were significantly higher in oxbow lakes than in other environments of the Upper Narew. The highest abundance

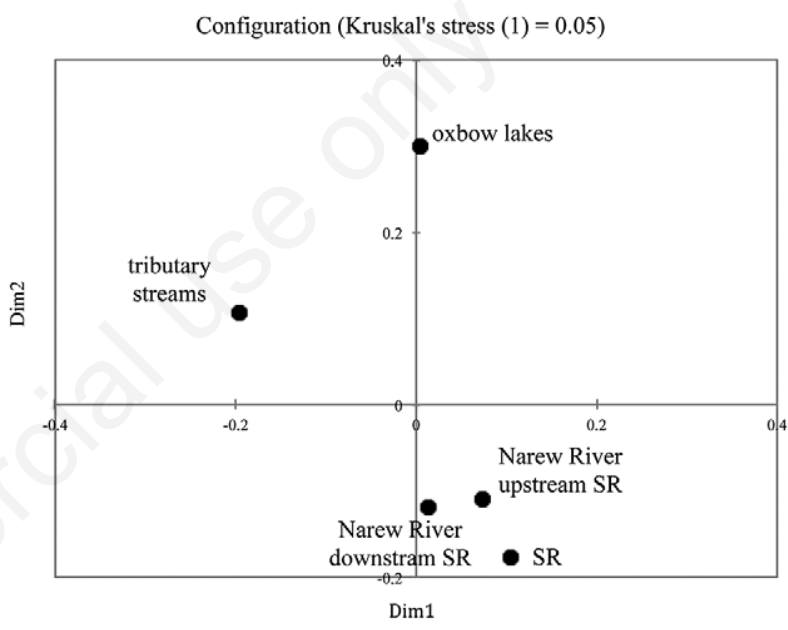

Fig. 2. Non-metric multidimensional scaling ordination of zooplankton communities in different environments of the Upper Narew River based on Bray-Curtis similarities of zooplankton communities. Plot shows the similarity of crustacean communities in different environments, according to the positions of their barycentres. SR, Siemianówka Reservoir.

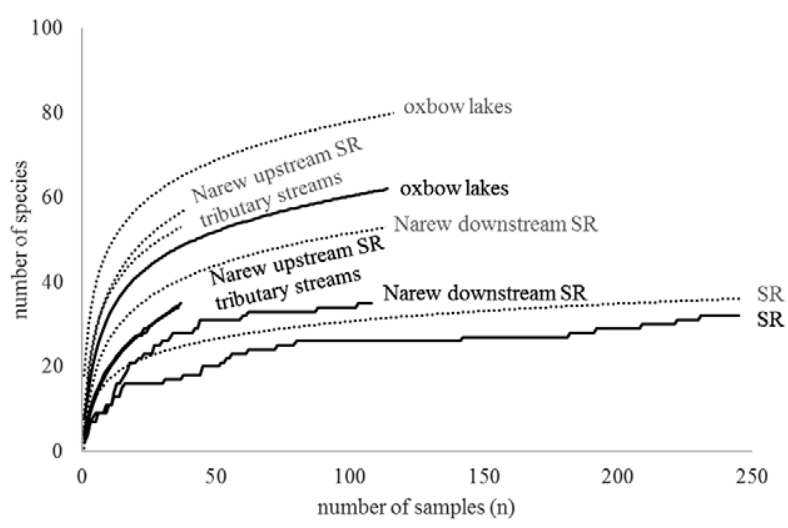

Fig. 3. Accumulated (solid line) and estimated by Chao2 (dotted line) crustacean species richness in different types of environments of the Upper Narew River. 
of crustacean zooplankton was found in the Siemianówka Reservoir (Fig. 4B). Different types of lotic environments showed similar values of crustacean communities parameters. There were no statistical differences in the Shannon index, average number of species, and abundance of zooplankton between the Narew River upstream SR, the Narew River downstream SR, and the tributary streams (Fig. 4). The Berger-Parker dominance index of crustacean communities was not significantly different between the studied environments (Fig. 4D).

A comparison of crustacean community diversities in oxbow lakes with various connections to riverbed revealed large differences (Tab. 2). Crustacean communities in semi-connected oxbow lakes had the highest number of species and Shannon index value and the lowest BergerParker dominance index value. Crustacean communities in closed lentic oxbow lakes had the lowest Shannon index value and evenness and the highest Berger-Parker dominance index value. Crustacean zooplankton were least abundant in lotic oxbow lakes. There were no significant differences between the abundance of zooplankton in semi-lotic and lentic oxbow lakes (Tab. 2).

\section{DISCUSSION}

In the Upper Narew Valley ( $\mathrm{n}=559$ ), were found 73 species of crustacean zooplankton, including 47 Clado-
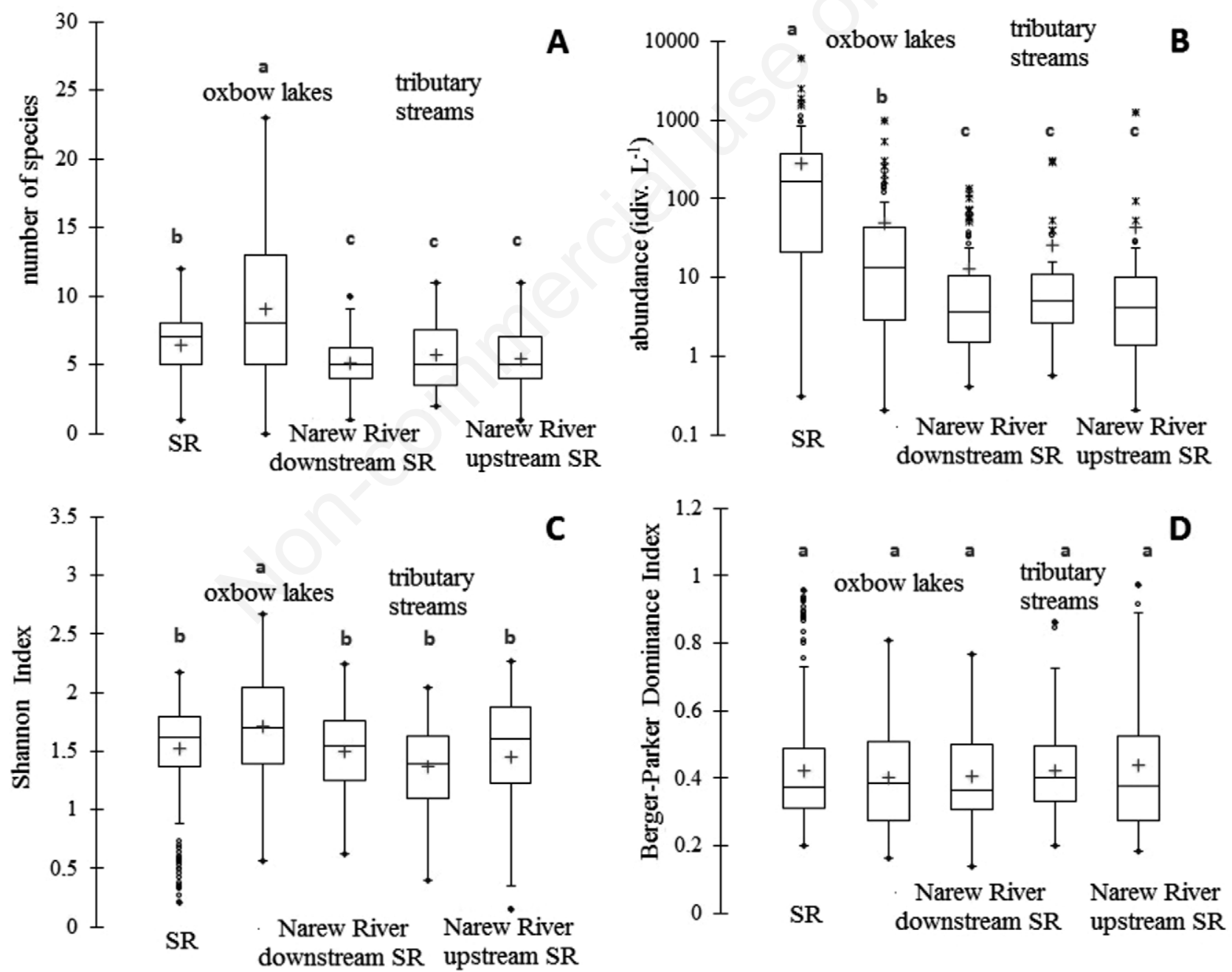

Fig. 4. Crustacean communities parameters in the different environments of the Upper Narew River: A) average number of species; B) abundance; C) Shannon index; D) Berger Parker dominance index. The crosses correspond to the means. The central horizontal bars are the medians. The lower and upper limits of the box are the first and third quartiles, respectively. Points above or below are minima and maxima, respectively. The different letters $(a, b, c)$ above the box plots denote significantly different values at $\mathrm{P} \leq 0.05$; same letters denote no statistically significant differences. 
cera and 26 Copepoda. It is about $50 \%$ of crustacean zooplankton species known from Poland (Rybak and Błędzki, 2010). Previous studies in the Narew National Park also revealed a high diversity of Crustacea. In the semi-natural Narew River ecosystems, researchers found 52 species $(\mathrm{n}=53)$, which is $30 \%$ more than in natural Biebrza River ( $\mathrm{n}=57)$ (Ejsmont-Karabin and Karabin, 2004). Similar numbers of crustacean species (50 Cladocera and 30 Copepoda species) were found in 274 shallow water bodies $(\mathrm{n}=1335)$ in central Poland. A study of pelagic and littoral microcrustacean species richness in 2466 Norwegian lakes recorded 120 crustacean species, including 77 cladocerans, 31 cyclopoids, and 12 calanoids. Few species were strictly pelagic, and the pelagic crustacean zooplankton species were far outnumbered by their littoral counterparts *(Walseng et al., 2006). However, in the pelagic zone of 1665 lakes in Canada, researchers recorded only 33 species of Cladocera (Pinel-Alloul et al., 2013), indicating the major contribution of littoral crustaceans to zooplankton species richness in lakes. Species numbers tend to increase with both the area surveyed and the number of samples taken (Azovsky, 2011). Zooplankton species richness in lakes increases with surface area but at an extremely slow pace. For example, two lakes with surface areas of 0.1 $\mathrm{km}^{2}$ and $1000 \mathrm{~km}^{2}$, respectively, would differ by only some five cladoceran species (Dumont and Segers, 1996). Further, space and time interact during the accumulation of species due to the common sample universe (Ulrich et al., 2013). According to the species accumulation curve, the estimated gamma diversity in the floodplain will probably increase with sampling effort during long-term research (Agostinho et al., 2004). The results of these studies revealed that it is necessary to take approximately 50-100 samples of zooplankton to establish crustacean species richness in various environments of a river valley.

Our results suggest that oxbow lakes are important for maintaining regional biodiversity of the river valley. More than $80 \%$ of all recorded crustacean species in Upper Narew Valley were found in oxbow lakes. The diversity in- dices of the crustacean communities were significantly higher in oxbow lakes than in other environments of the Upper Narew River. The species accumulation curves also revealed high crustacean richness in tributary streams and Narew River upstream SR. Generally, more heterogeneous habitats with macrophytes, such as small oxbow lakes and tributary streams, have higher crustacean species richness. However, the 'homogeneous' single sampling station in the Narew River upstream SR, which is surrounded by wetlands, also had high species richness. Natural riverine wetlands and oxbow lakes usually contain dense hygrophytic and aquatic vegetation, which are important habitats for zooplankton. Many studies have shown a great diversity of organisms in oxbow lakes, which are called 'hot spots' at the scale of a river valley or even a region (Paggi and Paggi, 1990; Tockner et al., 1998; Kuczyńska-Kippen and Nagengast, 2006; Lansac-Tôha et al., 2009; Pasztaleniec et al., 2013; Kuczyńska-Kippen and Joniak, 2015).

The degree of connectivity of floodplain lakes to the main rivers is also an important factor structuring aquatic communities in floodplain systems (Tockner et al., 1999; Bini et al., 2003; Velho et al., 2003; Alves et al., 2005; Thomaz et al., 2007; Lansac-Tôha et al., 2009). Connectivity, rather than the surface area of individual floodplain water bodies, explained local species richness (José de Paggi and Paggi, 2008). Species diversity patterns varied among taxa. The highest species richness values for mollusks were in open lotic oxbow lakes, for odonates in the semi-lotic oxbow lakes, and for macrophytes and amphibians in the closed lentic reservoirs (Tockner et al., 1999; Obolewski et al., 2009). Studies conducted in the Upper Narew Valley showed that semi-connected oxbow lakes had the highest diversity of microcrustaceans. This result supports the hypothesis that intermediate disturbance levels in riverine floodplains enhance biodiversity (Huston, 1979; Amoros and Bornette, 1999; Ward et al., 1999). Crustacean communities in closed-lentic oxbow lakes had the lowest Shannon index and the highest Berger-Parker dominance index because the communities were dominated by several microcrustacean species with the highest competi-

Tab. 2. Average values and standard deviation of zooplankton community structure parameters in oxbow lakes with various connections to the riverbed.

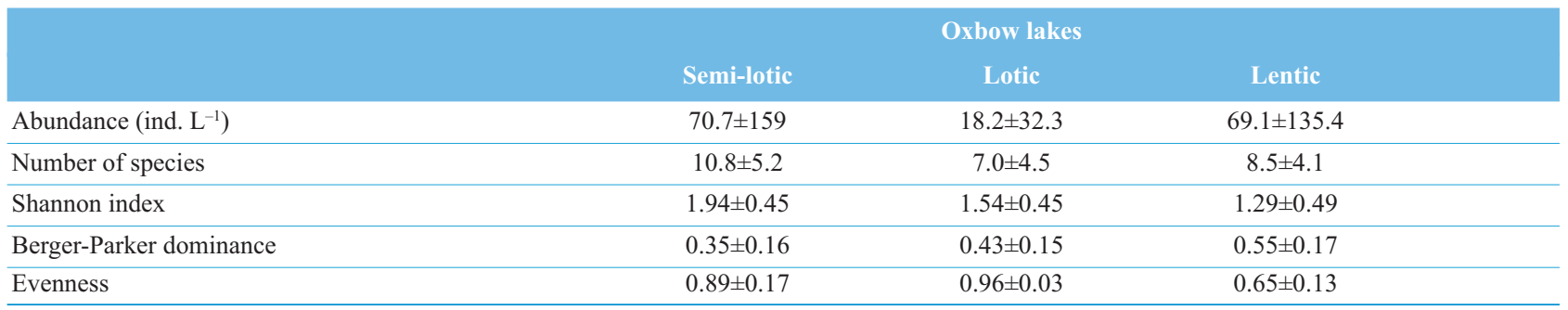


tive ability. In open-lotic oxbow lakes, which are unstable environments, crustacean communities were the least abundant and had the lowest number of species.

\section{CONCLUSIONS}

This study demonstrated that oxbow lakes are important for maintaining high regional biodiversity of floodplain rivers. More than $80 \%$ of all recorded crustacean species in the Upper Narew Valley were found in oxbow lakes. However, oxbow lakes with various connections to the riverbed had large differences in the diversity of crustacean communities. The highest species richness was observed in semi-lotic environments, which confirms that intermediate disturbance enhanced the biodiversity of water bodies in the floodplain river valley.

The species accumulation curves also showed high crustacean richness in tributary streams and in the Narew River upstream SR. Generally, more 'heterogeneous' habitats, such as small oxbow lakes and tributary streams, have higher crustacean species richness. However, the quite 'homogeneous' single sampling station in Narew River upstream SR, which is surrounded by wetlands, also had high species richness. Therefore, this information about spatial diversity patterns of microcrustacean communities should help reveal the importance of different types of water bodies and achieve sustainable river catchment management.

\section{REFERENCES}

Addinsoft, 2012. XLSTAT, Data analysis and statistics with Microsoft Excel. Paris, France.

Agostinho AA, Thomaz SM, Gomes LC, 2004. Threats for biodiversity in the floodplain of the Upper Paraná River: effects of hydrological regulation by dams. Ecohydrol. Hydrobiol. 4:255-268.

Amoros C, Bornette G, 1999. Antagonistic and cumulative effects of connectivity: a predictive model based on aquatic vegetation in riverine wetlands. Arch. Hydrobiol. 115:311-327.

Azovsky AI, 2011. Species-area and species-sampling effort relationships: disentangling the effects. Ecography 34:18-30.

Basualdo CV, 2011. Choosing the best nonparametric richness estimator for benthic macroinvertebrates databases. Rev. Soc. Entomol. Argent. 70:27-38.

Biggs J, Corfield A, Walker D, Whitfield M, Williams P, 1994. New approaches to the management of ponds. British Wildlife 5:273-287.

Bini LM, Velho LFM, Lansac-Tôha FA, 2003. The effect of connectivity on the relationship between local and regional species richness of testate amoebae (Protozoa, Rhizopoda) in floodplain lagoons of the Upper Paraná River, Brazil. Acta Oecol. 24:145-151.

Cazzanelli M, Warming TP, Christoffersen KS, 2008. Emergent and floating-leaved macrophytes as refuge for zooplankton in a eutrophic temperate lake without submerged vegetation. Hydrobiologia 605:113-122.
Colwell RK, 2013. EstimateS: Statistical estimation of species richness and shared species from samples. Ver. 9. Available from: http://purl.oclc.org/estimates

Dumont HJ, Segers H, 1996. Estimating lacustrine zooplankton species richness and complementarity. Hydrobiologia 341: 125-132.

Dussart BH, Defaye D, 2001. Introduction to the Copepoda. Backhuys Publ., Leiden: 344 pp.

Dziuba MK, Cerbin S, Wejnerowski Ł, 2013. Cladocera and Copepoda of the Shallow Eutrophic Lake in Natura 2000 Area in Western Poland. Pakistan J. Zool. 45:653-659.

Ejsmont-Karabin J, Karabin A, 2004. [Zespoły zooplanktonu w ekosystemach wodnych]. In: H. Banaszuk (ed.), [Przyroda Podlasia].[Book in Polish]. Narwiański Park Narodowy.

Flössner D, 2000. [Die Haplopoda und Cladocera (ohne Bosminidae) Mitteleuropas].[Book in German]. Backhuys Publ.: 428 pp.

Górniak A, Karpowicz M, 2014. Development of crustacean plankton in a shallow, polyhumic reservoir in the first 20 years after impoundment (northeast Poland). Inland Waters 4:311-318.

Grabowska M, 2005. Cyanoprokaryota blooms in the polyhumic Siemianówka dam reservoir in 1992-2003. Oceanol. Hydrobiol. Stud. 34:73-85.

Grabowska M, Mazur-Marzec H, 2014. Vertical distribution of cyanobacteria biomass and cyanotoxin production in the polymictic Siemianówka Dam Reservoir (eastern Poland). Arch. Pol. Fish. 22:41-51.

Gradziński R, Baryła J, Danowski W, Doktor M, Gmur D, Gradziński M, Kędzior A, Paszkowski M, Soja R, Zieliński T, Żurek S, 2000. Anastomosing system of the Upper Narew River, NE Poland. Ann. Soc. Geol. Pol. 70:219-229.

Hull A, 1997. The pond life project: a model for conservation and sustainability, p. 101-109. In: J. Boothby. (ed.), British Pond Landscape, Proceedings from the UK Conference of the Pond Life Project, Liverpool.

Huston M, 1979. A general hypothesis of species diversity. Am. Nat. 113:81-101.

José de Paggi SJ, Paggi JC, 2008. Hydrological connectivity as a shaping force in the zooplankton community of two lakes in the Paraná River floodplain. Int. Rev. Hydrobiol. 93:659-678.

Junk WJ, Bayley PB, Sparks RE, 1989. The flood pulse concept in river-floodplain systems. In: D.P. Dodge (ed.) Proc. Int. Large River Symposium. Can. Spec. Publ. Fish. Aquat. Sci. 106:110-127.

Kuczyńska-Kippen N, Joniak T, 2016. Zooplankton diversity and macrophyte biometry in shallow water bodies of various trophic state. Hydrobiologia 774:39-51.

Kuczyńska-Kippen N, Nagengast B, 2006. The influence of the spatial structure of hydromacrophytes and differentiating habitat on the structure of the rotifer and cladoceran communities. Hydrobiologia 559:203-212.

Lansac-Tôha FA, Bonecker CC, Velho LFM, Simões NR, Dias JD, Alves GM, Takahashi EM. 2009. Biodiversity of zooplankton communities in the Upper Paraná River floodplain: interannual variation from long-term studies. Braz. J. Biol. 69:S539-549.

Malanson GP, 1993. Riparian landscapes. Cambridge University Press, Cambridge: 296 pp.

McAleece N, Gage JDG, Lambshead PJD, Paterson GLJ, 1997. 
BioDiversity Professional statistics analysis software.

Obolewski K, Glińska-Lewczuk K, Kobus S, 2009. Effect of hydrological connectivity on the molluscan community structure in oxbow lakes of the Łyna River. Oceanol. Hydrobiol. Stud. 38:75-88

Obolewski K, Glińska-Lewczuk K, Ożgo M, Astel A, 2016. Connectivity restoration of floodplain lakes: an assessment based on macroinvertebrate communities. Hydrobiologia 774:23-37.

Paggi JC, José de Paggi SB, 1990. Zooplankton of the lotic and lentic environments of the middle Paraná River. Acta Limnol. Brazil. 3:685-719.

Pasztaleniec A, Karpowicz M, Strzałek M, 2013. The influence of habitat conditions on the plankton in the Białe oxbow lake (Nadbużański Landscape Park). Limnol. Rev. 13: 43-50.

Pinel-Alloul B, André A, Legendre P, Cardille AJ, Patalas K, Salki A, 2013. Large-scale geographic patterns of diversity and community structure of pelagic crustacean zooplankton in Canadian lakes. Global Ecol. Biogeogr. 22:784-795.

Pothoven SA, Fahnenstiel GL, 2015. Spatial and temporal trends in zooplankton assemblages along a nearshore to offshore transect in southeastern Lake Michigan from 2007 to 2012. J. Great Lakes Res. 41:95-103.

Rybak JI, Błędzki LA, 2010. [Słodkowodne skorupiaki planktonowe. Klucz do oznaczania gatunków].[Book in Polish]. Wyd. Uniwersytetu Warszawskiego.

Schneiders A, Verheyen R, 1998. A concept of integrated water management illustrated for Flanders (Belgium). Ecosystem Health 4:256-263.

Smirnov NN, 1996. Cladocera: the Chydoridae and Saycinae
(Chydoridae) of the world. SPC Academic Publ.: 203 pp. Stansfield JH, Perrow MR, Tench LD, Jowitt AJD, Taylor AAL, 1997. Submerged macrophytes as refuges for grazing Cladocera against fish predation: observations on seasonal changes in relation to macrophyte cover and predation pressure. Hydrobiologia 342:229-240.

Thomaz SM, Bini LM, Bozelli RL, 2007. Floods increase similarity among aquatic habitats in river-floodplain systems. Hydrobiologia 579:1-13.

Tockner K, Schiemer F, Baumgartner C, Kum G, Weigand E, Zweimüller I, Ward JV, 1999. The Danube restoration project: species diversity patterns across connectivity gradients in the floodplain system. Regul. River. 15:245-258.

Tockner K, Schiemer F, Ward JV, 1998. Conservation by restoration: the management concept for a river- floodplain system on the Danube River in Austria. Aquat. Conserv. 8:71-86.

Ulrich W, Zalewski M, Hajdamowicz I, Stańska M, Ciurzycki W, Tykarski P, 2013. Towards a general species -time - area - sampling effort relationship. Pol. J. Ecol. 61:345-354.

Walseng B, Hessen DO, Halvorsen G, Schartau AK, 2006. Major contribution from littoral crustaceans to zooplankton species richness in lakes. Limnol. Oceanogr. 51:2600-2606.

Ward JV, 1998. Riverine landscapes, biodiversity patterns, disturbance regimes, and aquatic conservation. Biol. Conserv. 83:269-278.

Ward JV, Tockner K, Schiemer F, 1999. Biodiversity of floodplain river ecosystems: ecotones and connectivity. Regul. River. 15:125-139.

Ward JV, Tockner K, 2001. Biodiversity: towards a unifying theme for river ecology. Freshwater Biol. 46:807-819. 